\title{
A Novel Mite-Transmitted Virus with a Divided RNA Genome Closely Associated with Pigeonpea Sterility Mosaic Disease
}

\author{
P. Lava Kumar, A. Teifion Jones, and D. V. R. Reddy
}

First and third authors: International Crops Research Institute for the Semi-Arid Tropics (ICRISAT), Patancheru 502 324 , India; and second author: Scottish Crop Research Institute, Invergowrie DD2 5DA, Scotland, U.K.

Accepted for publication 11 September 2002.

ABSTRACT

\begin{abstract}
Kumar, P. L., Jones, A. T., and Reddy, D. V. R. 2003. A novel mitetransmitted virus with a divided RNA genome closely associated with pigeonpea sterility mosaic disease. Phytopathology 93:71-81.

The agent of sterility mosaic, a disease that is a major constraint on pigeonpea (Cajanus cajan) production in the Indian subcontinent, is transmitted by the eriophyid mite, Aceria cajani. This agent has remained elusive for decades despite intensive efforts but we report the isolation of highly flexuous filamentous virus-like particles (VLPs) of 3 to $10 \mathrm{~nm}$ in width and of undefined lengths from sterility mosaic disease (SMD)affected pigeonpea plants. Purified VLP preparations from virus-infected pigeonpea and Nicotiana benthamiana had a buoyant density in cesium chloride of 1.22 to $1.23 \mathrm{~g} \mathrm{~cm}^{-3}$ and contained a major virus-specific protein species of $\approx 32 \mathrm{kDa}$ and 5 to 7 RNA species of $\approx 6.8$ to $1.1 \mathrm{~kb}$. The sequence of some complementary DNA clones to RNA from purified VLP preparations had no significant matches in database searches. Two oligonucleotide primers derived from one such sequence, when used in reverse transcriptase-polymerase chain reaction assays, amplified a pro-
\end{abstract}

duct of 321 bp specifically from SMD-affected pigeonpea plants. Purified VLP preparations were used to produce polyclonal antibodies that, in infected plants, detected the virus using enzyme-linked immunosorbent assay (ELISA) and the virus-specific 32-kDa protein in western immunoblotting (WIB). In such assays, the virus was detected consistently in all SMD-affected pigeonpea plant samples from several different locations in India, but not in samples from symptom-free pigeonpea plants from the same locations. In experimental studies, all pigeonpea plants inoculated with viruliferous $A$. cajani and those plants graftinoculated with SMD-affected tissue were infected with the virus as assessed by ELISA and WIB, but not any uninfected pigeonpea plants. This virus, tentatively named Pigeonpea sterility mosaic virus (PPSMV), has some properties similar to virus species in the genera Tospovirus and Tenuivirus and with the eriophyid mite-transmitted High plains virus (HPV) but is distinct from these and from all other characterized viruses. The combination of novel properties shown by PPSMV and HPV suggest that they may constitute species in a new genus of plant viruses.
Pigeonpea (Cajanus cajan, family Fabaceae) is a major grain legume crop, seed of which supplies dietary protein requirements to large populations of people living in the semiarid tropics of the Indian subcontinent. Sterility mosaic disease (SMD), a major constraint on pigeonpea production, was first described in 1931 in Bihar State, India (35) and subsequently from several states of India and from Bangladesh, Nepal, Thailand, Myanmar, and Sri Lanka (42). Estimated yield losses in India due to SMD were over 205,000 ton of grain per annum, valued at more than US\$70 million during 1975 to 1980 (22), equivalent to a current value of more than US $\$ 250$ million. More recent studies on economic losses due to SMD are lacking but it remains the most important disease of pigeonpea $(36,42,49)$. The disease is characterized by sterility (complete or partial cessation of flower production), mosaic symptoms on leaves (Fig. 1B), excessive vegetative growth, severe stunting, and reduction in leaf size (42). SMD symptoms vary depending on the pigeonpea genotype and are categorized into three types: (i) severe mosaic (Fig. 1B) and sterility, (ii) mild mosaic (Fig. 1D) with partial sterility, and (iii) chlorotic ring spots (Fig. 1C) without any noticeable sterility. The SMD causal agent is not known but graft transmission experiments showed that it was an infectious agent (7). Under natural conditions, the eriophyid mite, Aceria cajani Channabasavanna

Corresponding author: A. T. Jones; E-mail address: tjones@scri.sari.ac.uk

Publication no. P-2002-1115-02R

This article is in the public domain and not copyrightable. It may be freely reprinted with customary crediting of the source. The American Phytopathological Society, 2003.
(Acari: Arthropoda), transmits the agent (48). This mite is highly host specific and is restricted to pigeonpea and a few of its wild relatives (28).

The SMD agent has remained elusive to identification and characterization despite several attempts over several decades (36, 49). However, previous studies demonstrated that it was not a fungus or a bacterium. The search for a phytoplasma-like agent by electron microscopy of ultrathin sections of diseased tissues and by the application of tetracycline treatments indicated that such agents were unlikely to be involved (15). The invariable association of vector mites with diseased plants led to a speculation that SMD may be the result of mite toxemia. However, this was excluded by critical experiments using SMD agent-free mite colonies on SMD-susceptible pigeonpea cultivars $(15,24)$. Based on symptoms and transmission by mites, the SMD agent was assumed to be a virus. However, efforts to isolate a putative virus or virus-like agent using various techniques were not successful $(36,43)$.

Several other eriophyid mite-transmitted disease agents infecting dicotyledonous plants also have remained intractable to study for many decades (38) but, in the last few years, progress has been made in identifying the causal agents of three such diseases $(16,18,19,33)$. With the exception of Blackcurrant reversion virus (BRV), all known mite-transmitted viruses have flexuous rodshaped or filamentous particles $(16,18,19,33)$. Eriophyid mites, particularly A. cajani, possesses a short stylet of $\approx 2.03 \mu \mathrm{m}$ that permits penetration into only epidermal and, at most, underlying mesophyll cells (44). Therefore, mites can only acquire the disease agent if it is present in such plant cells. Usually, viruses occurring in such tissues are transmitted mechanically in sap extracts. Indeed, all the characterized mite-transmitted viruses 
(BRV, High plains virus [HPV], Peach mosaic virus, and PPSMV) are transmissible in this way although, for some, only with great difficulty $(16,18,21,33,38)$.

Against this background, we have assumed that host polyphenolic compounds interfere with the stability and/or the infectivity of the SMD agent, thereby inhibiting mechanical transmission. A purification procedure to minimize the influence of such components before inoculation onto herbaceous test plants led to the isolation of an Aureusvirus from pigeonpea (27), but this virus was present in only some SMD-infected plants and also in healthy plants (27). Simultaneously, attempts were made to isolate and purify the SMD causal agent directly from SMD-affected pigeonpea using methods for isolating viruses from woody plants or for unstable viruses. In this article, we report the isolation of a novel virus, tentatively named Pigeonpea sterility mosaic virus (PPSMV), describe its major properties and methods for its detection, and demonstrate its invariable association with SMD. Brief abstracts of this study have been published $(26,29)$.

\section{MATERIALS AND METHODS}

Plant material and SMD culture. Mites from SMD-affected pigeonpea plants maintained at the International Crops Research Institute for the Semi-Arid Tropics (ICRISAT), Patancheru, India, were used for virus transmission. Inoculum was maintained in the SMD-susceptible pigeonpea cv. ICP8863 by viruliferous mites using the leaf stapling technique (37). Inoculated plants were kept in a growth chamber maintained at $27^{\circ} \mathrm{C}$ with $55 \%$ humidity during the day $(14 \mathrm{~h})$ and $18^{\circ} \mathrm{C}$ and $35 \%$ humidity during the night $(10 \mathrm{~h})$. SMD cultures also were established by leaflet grafting (42) and were maintained in a separate mite-free growth chamber kept at the same conditions as described previously. Uninoculated pigeonpea cvs. ICP8863 and ICP7035 (resistant to SMD) were maintained separately to use as diseasefree controls.
Mechanical transmission and host range. Sap from fresh leaves of SMD-affected pigeonpea was extracted in three volumes of 2\% nicotine solution (Sigma, Gillingham, Dorset, UK) or in

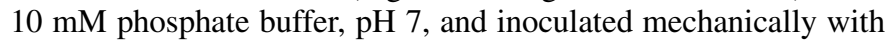
the forefingers onto corundum-dusted leaves of Brassica pekinensis, Chenopodium amaranticolor, Chenopodium murale, Chenopodium quinoa, Cucurbita pepo, Lycopersicon esculentum, Nicotiana benthamiana, N. clevelandii, N. debnyii, N. glutinosa, $N$. megalosiphon, $N$. occidentalis accessions $\mathrm{P}$ and $37 \mathrm{~B}, N$. tabacum cvs. Samsun, White Burley, and Xanthi N/N, Petunia hybrida, Spinacea oleracea, and Vicia faba cv. The Sutton, and to pigeonpea cv. ICP8863. Assays for PPSMV in inoculated and uninoculated apical leaves of test plants were assessed 25, 40, 60, and 80 days postinoculation (dpi) by enzyme-linked immunosorbent assay (ELISA) using PPSMV antiserum. Longevity of infectivity in vitro was determined with infected sap extracted in one or three volumes of $2 \%$ nicotine solution and also in intact leaves stored at 4 and $-20^{\circ} \mathrm{C}$. Leaves of 9- to 14-day-old pigeonpea seedlings and of $N$. benthamiana plants were rinsed with bentonite buffer ( $10 \%$ bentonite in $10 \mathrm{mM}$ Tris- $\mathrm{HCl}, \mathrm{pH} \mathrm{7.6)}$, dusted with corundum, and inoculated with purified PPSMV preparations or nucleic acid preparations diluted in an equal volume of $2 \%$ nicotine solution or bentonite buffer. Attempts were made to transmit PPSMV from $N$. benthamiana to pigeonpea (cv. ICP8863) by chip and leaflet grafting using petiole and stem stocks of PPSMV-infected $N$. benthamiana $(20,41)$.

Virus purification. Procedures reported for the purification of Maize stripe virus (MSpV) (40), the nucleoprotein of Tomato spotted wilt virus (9), Peach mosaic virus (16), and BRV (33), and a minipurification protocol of Lane (32) were evaluated for purification from SMD-affected pigeonpea. At various steps in the purification procedures, preparations were monitored by electron microscopy, polyacrylamide gel electrophoresis (PAGE), and ELISA for PPSMV. The final purification procedure adopted is described below. Preparations from leaves

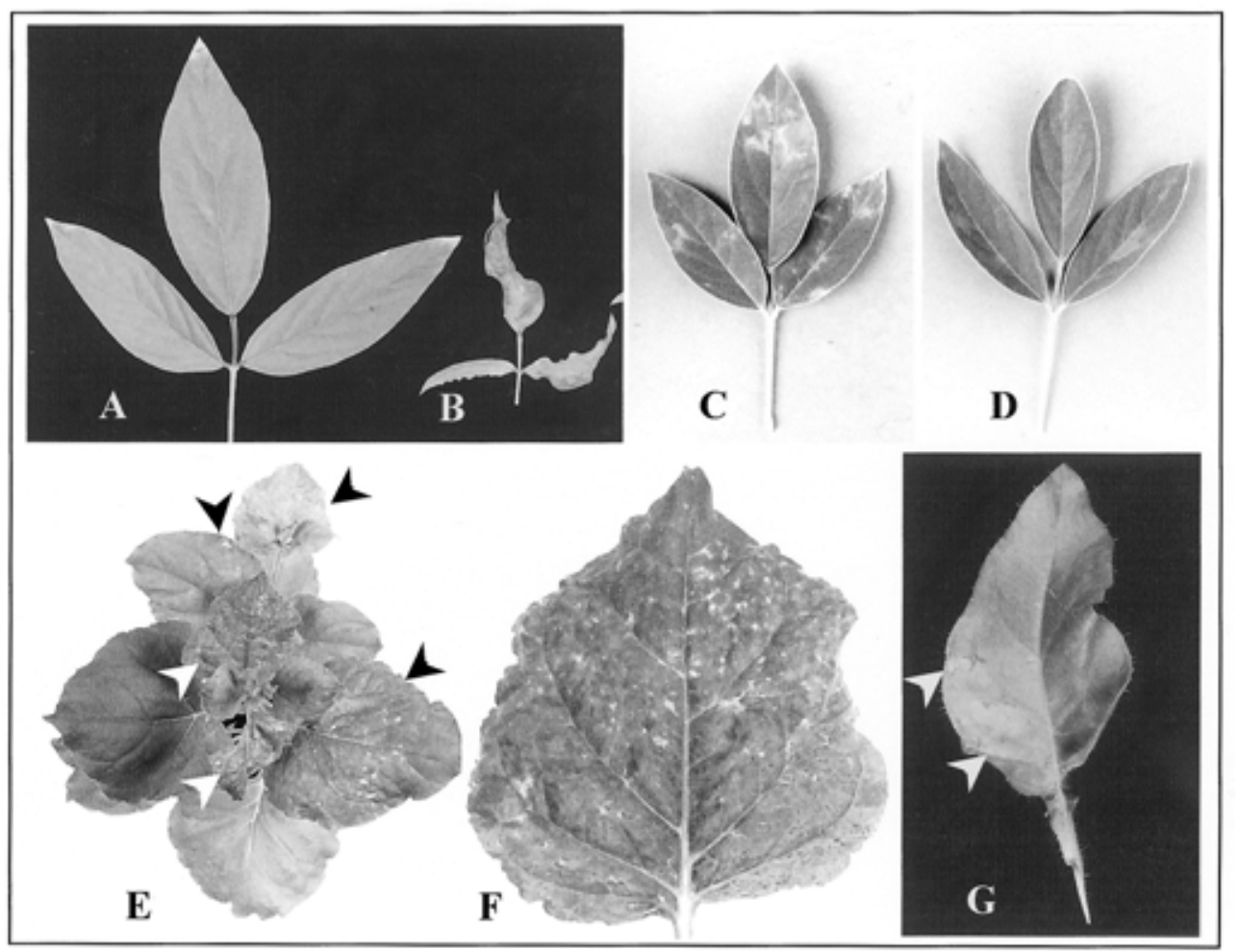

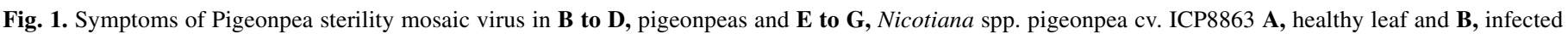

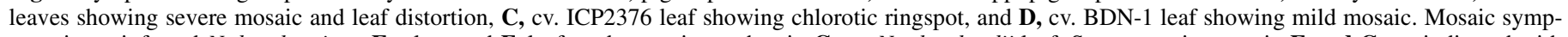

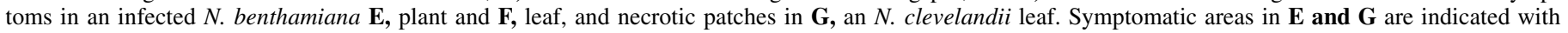
arrowheads. 
of uninfected pigeonpea and $N$. benthamiana were used as controls.

For virus purification, $75 \mathrm{~g}$ leaf material was homogenized in $400 \mathrm{ml}$ of ice cold homogenization buffer (HB; $0.05 \mathrm{M}$ Tris, pH 8, containing $1 \% \alpha$-monothioglycerol, $0.02 \mathrm{M}$ EDTA, $0.25 \mathrm{M}$ sodium sulfite, $1 \%[\mathrm{wt} / \mathrm{vol}]$ polyvinyl pyrrolidone [molecular weight $=40,000]$ and $0.02 \mathrm{M}$ sodium diethyldithiocarbamte [DIECA]) in a Waring blender (Waring Products, New Hartford, CT). The homogenate was filtered through cheesecloth and centrifuged at 2,600 $\times g$ for $4 \mathrm{~min}$. To the supernatant fluid was added polyethylene glycol (molecular weight $=6,000)$ to $8 \%(\mathrm{wt} / \mathrm{vol})$, $\mathrm{NaCl}$ to $0.2 \mathrm{M}$, and Triton $\mathrm{X}-100$ to $20 \%$ (vol/vol), and the mixture stirred for $1 \mathrm{~h}$ at $4{ }^{\circ} \mathrm{C}$ before centrifuging at $10,000 \times g$ for $20 \mathrm{~min}$. The pellets were resuspended in $150 \mathrm{ml}(2 \mathrm{ml} / \mathrm{g}$ of leaf $)$ of $1: 10 \mathrm{HB}$ in sterile distilled water (resuspension buffer [RB]) and clarified with $30 \%$ (vol/vol) chloroform. The emulsion was centrifuged at $10,000 \times g$ for $10 \mathrm{~min}$ and the upper aqueous phase was collected and layered onto a $2-\mathrm{cm}$ cushion of $20 \%(\mathrm{wt} / \mathrm{vol})$ sucrose in RB Beckman SW28 Ultra-clear tubes and centrifuged at $104,000 \times g$ for $2 \mathrm{~h}$. Further purification was achieved by layering partially purified preparations onto $42 \%$ (wt/vol) $\mathrm{CsCl}$ in $0.01 \mathrm{M}$ Tris-HCl, pH 7.5, in Beckman SW41 Ultra-clear tubes and centrifuging at $187,000 \times g$ for $3 \mathrm{~h}$. The light-scattering zone that formed was collected, diluted in RB, and concentrated by centrifuging at $122,000 \times g$ for $90 \mathrm{~min}$, and the pellets were resuspended in $250 \mu \mathrm{l}$ of RB.

For buoyant density estimation, purified preparations from PPSMV-infected and from healthy plants were layered onto $42 \%$ (wt/vol) $\mathrm{CsCl}$ in Beckman SW41 Ultra-clear tubes and centrifuged to equilibrium for $18 \mathrm{~h}$ at $160,000 \times g$. Gradients were fractionated by upward displacement into individual 12-drop fractions using an ISCO density gradient fractionator. Then $40 \mu \mathrm{l}$ of each fraction, either independently or mixed with successive fractions, was analyzed by PAGE and western immunoblotting (WIB), and 1:1,000 diluted fractions were assayed by ELISA. The refractive index of virus-containing fractions was measured using an ATAGO digital refractometer (Jencons Ltd., Leighton Buzzard, Bedfordshire, UK).

Electron microscopy. Purified preparations from healthy and infected plants of pigeonpea and $N$. benthamiana were resuspended in $\mathrm{RB}$ and a drop applied to carbon-coated grids and stained with $2 \%$ aqueous uranyl acetate, $\mathrm{pH} 3.5$, and viewed in a transmission electron microscope (1200EX; JEOL Ltd., Grosiden, Herts, UK).

Production of polyclonal antibodies. Antiserum to purified virus particle preparations was produced in a New Zealand White inbred rabbit by four weekly intramuscular injections of $250 \mu \mathrm{l}$ of purified virus preparations in phosphate-buffered saline mixed with an equal volume of Freund's complete adjuvant (Sigma) in the first injection, and incomplete adjuvant in the subsequent injections. Fourteen days after the final injection, the animal was bled at weekly intervals.

Serological assays. For virus detection, direct antigen coating (DAC)-ELISA as described previously (17) was used. Leaf samples were ground in carbonate buffer, $\mathrm{pH} 9.6,(1: 10$, wt/vol) and added to wells of MaxiSorp ELISA plates (Nunc, Fisher Scientific, Loughborough, UK). Polyclonal antiserum was used at 1:5,000 dilution after cross-absorbing with healthy pigeonpea (cv. ICP8863 or cv. ICP7035) leaf sap at $10 \mathrm{mg} / \mathrm{ml}$ in phosphatebuffered saline containing $0.2 \%$ ovalbumin and $2 \%$ PVP, at $37^{\circ} \mathrm{C}$ for $45 \mathrm{~min}$. Alkaline phosphatase (ALP)-labeled goat anti-rabbit immunoglobulin $\mathrm{G}$ (IgG) (Sigma) was used at 1:4,000 dilution for detecting the immobilized antigen-antibody complex, and $p$-nitrophenylphosphate (Sigma) as the substrate for the ALP at $5 \mathrm{mg} / \mathrm{ml}$ in $10 \%(\mathrm{vol} / \mathrm{vol})$ diethanolamine buffer, $\mathrm{pH}$ 9.8. Absorbance at $405 \mathrm{~nm}\left(A_{405 \mathrm{~nm}}\right)$ readings were taken after incubation at room temperature for up to $2 \mathrm{~h}$, in a Multiscan Plus ELISA plate reader (Labsystems, Helsinki, Finland). $A_{405 \mathrm{~nm}}$ values greater than $2 \times$ those of healthy controls were considered as PPSMV positive. All tests were made in duplicate wells and replicated three times in different plates. Assessment of serological relationships with other viruses were tested by ELISA using antiserum against MSpV (40), Peanut bud necrosis virus (PBNV) N-antiserum (ICRISAT), High plains virus (HPV) (19), Ranunculus white mottle virus (RWMV) (51), Citrus psorosis virus (CPsV) (3), and Mirafiori lettuce virus (MiLV) (45). All the antisera were tested at two dilutions of 1:500 and 1:1,000 after cross-absorbing with healthy pigeonpea leaf extracts.

Analysis of proteins by PAGE, WIB, and matrix-assisted laser desorption ionization-time of flight. Purified preparations from healthy and from SMD-affected plants were denatured by boiling for $3 \mathrm{~min}$ in an equal volume of Laemmli sample buffer (LSB) and were electrophoresed in a $12 \%$ sodium dodecyl sulfate (SDS)-discontinuous polyacrylamide gel (Model V16, BRL, Cambridge, UK) (31). Low-range prestained protein standards were used as markers (Cat. 161-0303, Bio-Rad, Hemel Hempstead, Hertfordshire, UK) and gels were silver stained for protein detection (47). For WIB, purified protein samples or total leaf protein extracts prepared in RB (1:10, wt/vol) were mixed with an equal volume of LSB and separated by SDS-PAGE. The denatured proteins from the gel were blotted onto nitrocellulose membrane (Bio-Rad) and probed with 1:5,000 dilution of crossabsorbed antiserum to PPSMV. Reactions were detected with ALP-labeled anti-rabbit $\operatorname{IgG}$ at 1:5,000 dilution and reactions identified colorimetrically with 5-bromo-4-chloro-3-indolyl-phosphate/4-nitroblue tetrazolium chloride (BCIP/NBT) solution (5).

Mass spectrometry was used to identify the proteins present in purified PPSMV preparations from healthy and PPSMV-infected pigeonpea and $N$. benthamiana. Purified preparations were separated in a $12 \%$ SDS-PAGE and gels were stained with colloidal blue (Invitrogen, Groningen, The Netherlands). The 32- and $52-\mathrm{kDa}$ proteins from preparations of PPSMV-infected plants and the 52-kDa protein from preparations from uninfected plants were excised from the gel and digested in-gel with trypsin (Sigma) and prepared for matrix-assisted laser desorption ionization-time of flight (MALDI-ToF) analysis as described previously (39) and $1 \mu \mathrm{l}$ of the sample was analyzed on a PerSeptive Biosystems VoyagerElite MS (Framingham, MS). A peptide mass fingerprinting search was made by inputting experimental monoisotopic masses of the peptide fragments generated by MALDI with $\mathrm{m} / \mathrm{z}$ ratios between 600 and 3,000 into the MS-fit program (8) with carbamidomethylation of cystein residue and oxidation of methionine as fixed and variable modifications, respectively. The search was made against the theoretical masses of the trypsin digest of entire nucleic acid sequences in the National Center for Biotechnology Information (NCBI-nr) database, with one missed cleavage and \pm 0.5 Da peptide mass tolerance.

Analysis of viral nucleic acids. Purified virus preparations were mixed with $10 \%$ SDS to a final concentration of $1 \%(\mathrm{vol} / \mathrm{vol})$ and extracted twice with phenol/chloroform (5:1, vol/vol). RNA from the aqueous phase was concentrated using the RNaid kit following the manufacturer's instructions (BIO 101, Harefield, Middlesex, UK). Preparations then were treated with Proteinase K $(30 \mu \mathrm{g}$ per $100 \mu \mathrm{l})$ (Roche, Lewes, East Surrey, UK), extracted with phenol/chloroform, and RNA from the aqueous phase was concentrated using the RNaid kit. Aliquots of such nucleic acid preparations were electrophoresed in a $1 \%$ agarose gel in Trisborate EDTA (TBE) buffer, $\mathrm{pH} 8.3$, or in formaldehyde denaturing $1 \%$ agarose gels (46). Gels were stained with ethidium bromide and viewed under a UV-transilluminator. Single-stranded RNA (ssRNA) markers were used as size standards (Cat. G319A, Promega, Southampton, UK). The viral nucleic acids were digested with RNase-free DNase I (Promega) and RNase A (Qiagen, Crawley, West Sussex, UK). To determine the strandedness, the viral nucleic acid was treated with RNase A in low salt $(0.02 \times$ $\mathrm{SSC}$ buffer $[1 \times \mathrm{SSC}$ is $0.15 \mathrm{M} \mathrm{NaCl}$ plus $0.015 \mathrm{M}$ sodium cit- 
rate], $\mathrm{pH} 7$ ) and high salt ( $2 \times \mathrm{SSC}$ buffer) and incubated at 37 and $4^{\circ} \mathrm{C}(50)$. Nucleic acids also were analyzed by lithium chloride fractionation. Preparations were mixed with an equal volume of $4 \mathrm{M} \mathrm{LiCl}$ and the solution was kept at $4^{\circ} \mathrm{C}$ overnight, and centrifuged at $12,000 \times g$ for $10 \mathrm{~min}$. Nucleic acid from the supernatant and pellet fractions was extracted separately using the RNaid kit and analyzed by electrophoresis as described previously.

cDNA synthesis and sequencing. Purified viral RNA $(2 \mu \mathrm{g})$ was mixed with $4.5 \mu \mathrm{g}$ of random hexamers (Promega) and the mixture was denatured with $20 \mathrm{mM}$ methyl mercuric hydroxide for $30 \mathrm{~min}$ at room temperature and quenched on ice for $10 \mathrm{~min}$. The mixture then was used for cDNA synthesis using the Universal Riboclone Synthesis kit (Promega) and cloned into the pCR4-Blunt TOPO vector (Invitrogen) as described previously (27). Recombinant clones were screened for inserts and clones containing inserts of $>400$ bp were isolated using the QIAminiprep kit (Qiagen) and sequenced by dideoxy sequencing using the Universal M13 forward and reverse primers as described previously (25). Sequences were analyzed using the ABI Sequence Navigator version 1.0.1 and the Wisconsin Software Package version 10.1 (Genetics Computer Group, Madison, WI). All sequences were compared with those in the GenBank/EMBL database using the BLAST program (4).

Northern hybridization and reverse transcriptase-polymerase chain reaction. Total RNA from $150 \mathrm{mg}$ of leaves from healthy and from PPSMV-infected plants was extracted using the
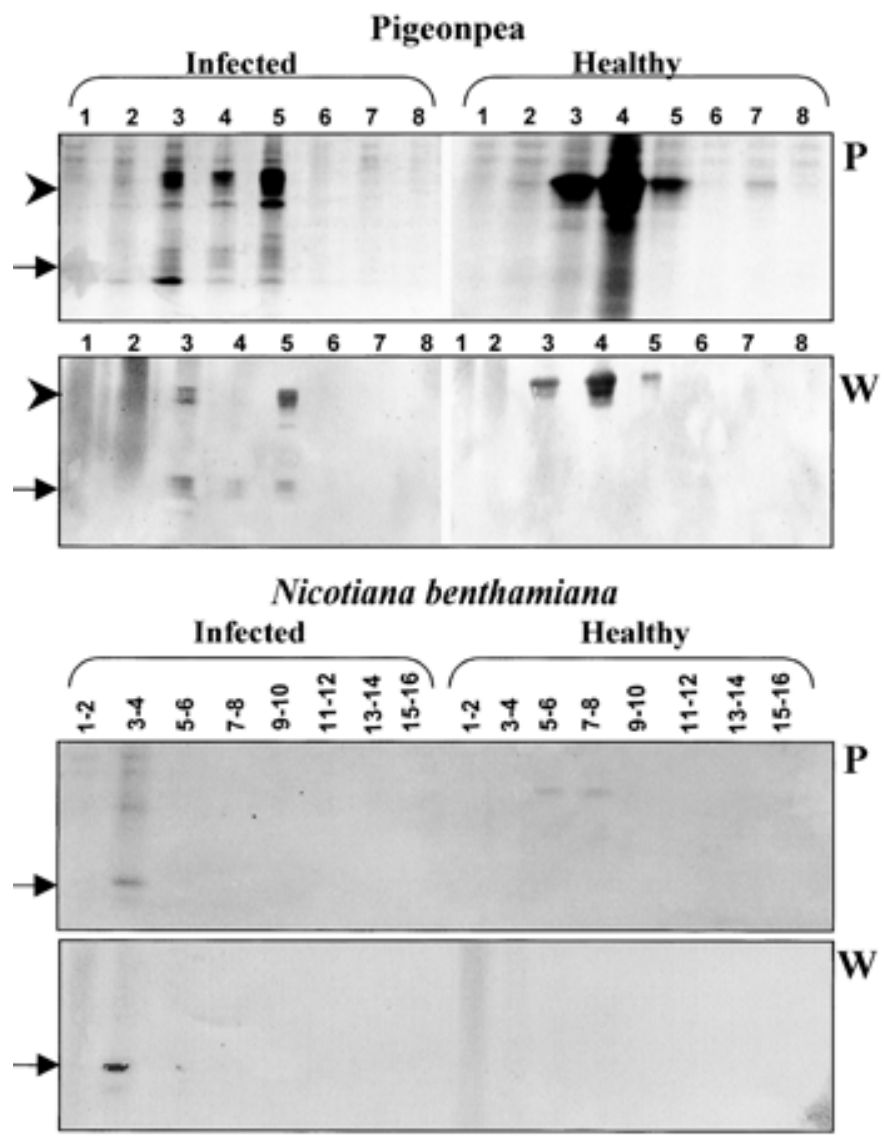

Fig. 2. Analysis by polyacrylamide gel electrophoresis (P) and western immunoblotting (W) of fractions obtained from a cesium chloride density gradient following ultracentrifugation of preparations purified from healthy and Pigeonpea sterility mosaic virus (PPSMV)-infected pigeonpea cv. ICP8863 and Nicotiana benthamiana plants. Gradient fraction numbers are indicated on respective lanes. Polyacrylamide gels were silver stained and western blots were probed with PPSMV polyclonal antiserum. Arrowheads indicate the $52-\mathrm{kDa}$ protein present in preparations from healthy and infected plants, and the arrows indicate the PPSMV-specific 32-kDa protein.
Plant RNeasy mini kit (Qiagen). Purified viral RNA and total RNA samples were prepared for Northern hybridization as described by Sambrook et al. (46) and electrophoresed in TBE or formaldehyde denaturing $1 \%$ agarose gels. The gels were blotted onto positively charged nylon membrane (Roche) using $5 \times$ SSC containing $10 \mathrm{mM} \mathrm{NaOH}$ as the transfer buffer (46). After transfer, the membrane was viewed on a UV transilluminator, the positions of the ssRNA markers were marked on the reverse side of the membrane with a pencil, and the RNA was cross-linked by UV irradiation at $254 \mathrm{~nm}$ for $100 \mathrm{~s}$ at $1.5 \mathrm{~J} / \mathrm{cm}^{2}$. The membranes were processed with a digoxigenin (DIG)-labeled probe prepared by polymerase chain reaction (PCR) from a cDNA clone ( $c d 1.1$; 764-bp insert) with the PCR-DIG labeling mix following the manufacturer's instructions (Cat. 1277065, Roche). Prehybridization and hybridization was done in NorthernMax Prehyb/Hyb buffer (Ambion, Huntingdon, UK) at $50^{\circ} \mathrm{C}$. After overnight hybridization, membranes were washed twice with $2 \times$ SSC containing $0.5 \%$ SDS and twice with $0.1 \times$ SSC containing $0.1 \%$ SDS at temperatures used for hybridization. Hybridization reactions were detected chromogenically using anti-DIG ALP-antibodies and BCIP/NBT substrate following the manufacturer's instructions (Cat. 1681451, Roche).

Oligonucleotide primers SMV-1 (5'-ACAT AGTT CAAT CCTT GAGT GCG- $\left.3^{\prime}\right)$ and SMV-2 (5'-ATAT TTTA ATAC ACTG ATAG GA-3') were designed from the nucleotide sequence of clone $c d 1.1$ for the amplification of a 321-bp product. Primers were tested for PPSMV detection by reverse-transcription (RT)-PCR using RNA from purified PPSMV preparations and total RNA from $150 \mathrm{mg}$ of leaf tissue extracted with the Plant RNeasy kit (Qiagen). Sterile water $(11 \mu \mathrm{l})$ containing 1 to $4 \mu \mathrm{l}$ of template and $50 \mathrm{ng}$ of SMV-1 and SMV-2 primers was denatured at $70^{\circ} \mathrm{C}$ for $10 \mathrm{~min}$ and snap cooled on ice. To this was added $9 \mu \mathrm{l}$ of the first strand reaction mixture $\left(2 \mu \mathrm{l}\right.$ of $25 \mathrm{mM} \mathrm{MgCl}_{2}, 2 \mu \mathrm{l}$ of $0.1 \mathrm{M}$ DTT, $1 \mu \mathrm{l}$ of $10 \mathrm{mM}$ dNTP mixture, $4 \mu \mathrm{l}$ of $5 \times$ RT buffer [Promega],

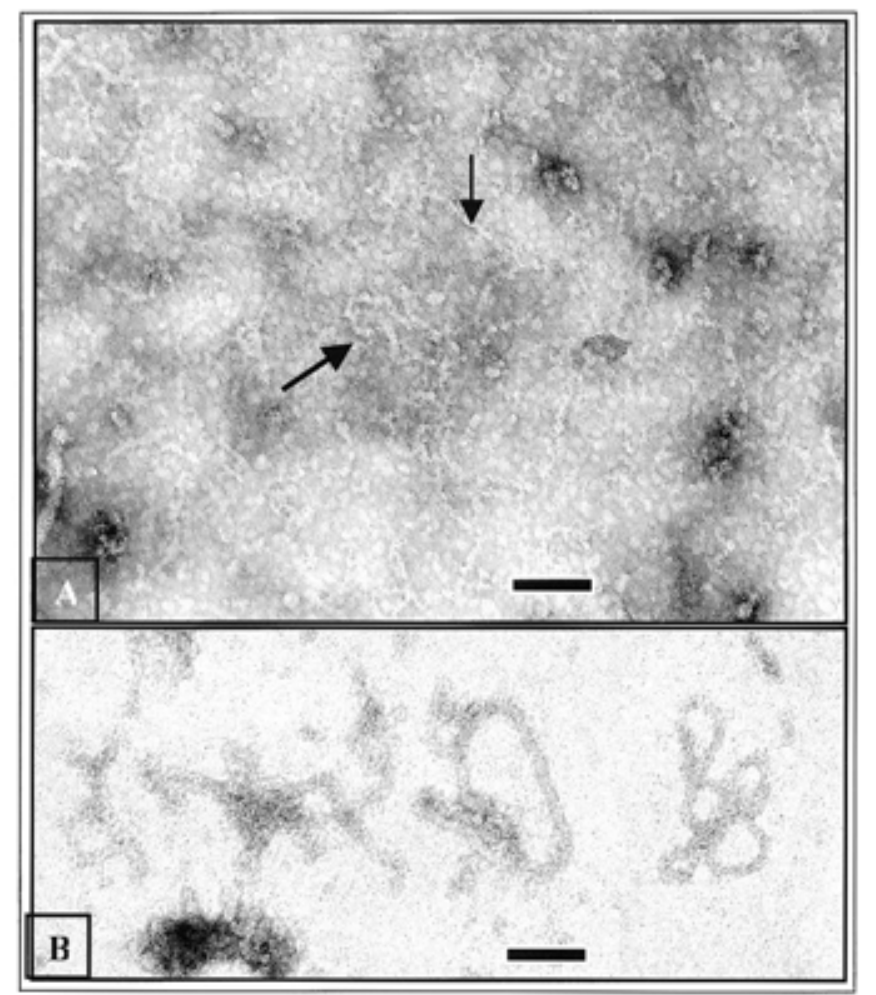

Fig. 3. Electron micrographs of purified virus-like particle preparations of Pigeonpea sterility mosaic virus in uranyl acetate, $\mathrm{pH} 3.5$, showing the $\mathbf{A}$, linear (see arrows) and $\mathbf{B}$, branched and circular structure of the virus-like particles. The nature of the shorter flexuous particles is not known but they were also found in preparations from healthy plants. Bars $=100 \mathrm{~nm}$. 
10 units of RNasin and 100 units of Moloney murine leukemia virus RT [Promega]) and the mixture was incubated at $42^{\circ} \mathrm{C}$ for $45 \mathrm{~min}$. First strand reaction mixture $(10 \mu \mathrm{l})$ was added to the PCR reaction mixture $(5 \mu \mathrm{l}$ of $10 \times$ Taq buffer [Promega], $3 \mu \mathrm{l}$ of $25 \mathrm{mM} \mathrm{MgCl}_{2}, 1 \mu \mathrm{l}$ of $10 \mathrm{mM}$ dNTP mixture, 0.5 units of Taq [Promega], distilled water to $50 \mu \mathrm{l}$ ) containing $50 \mathrm{ng}$ of SMV-1 and SMV-2 primers and amplified by PCR using the following cycle parameters: $94^{\circ} \mathrm{C}$ for $5 \mathrm{~min}$ of denaturation; followed by 35 cycles of amplification by denaturation at $94^{\circ} \mathrm{C}$ for $45 \mathrm{~s}$, annealing at $55^{\circ} \mathrm{C}$ for $45 \mathrm{~s}$, and extension at $72^{\circ} \mathrm{C}$ for $60 \mathrm{~s}$; and final extension at $72^{\circ} \mathrm{C}$ for $5 \mathrm{~min}$. The amplified product $(30 \mu \mathrm{l})$ was analyzed in $1 \%$ TBE agarose gels (46). DNA Marker VIII (Cat. 1336045, Roche) was used as size standards.

\section{RESULTS}

Mechanical transmission and host range of PPSMV. Of the herbaceous species inoculated with sap extracted from SMDaffected pigeonpea in $2 \%$ nicotine solution, only $N$. benthamiana was infected by PPSMV at $40 \mathrm{dpi}$. When individual leaves of these infected $N$. benthamiana plants were tested by ELISA, PPSMV was detected in only a few apical leaves of primary and secondary branches, indicating an erratic distribution of the virus in these plants. Young leaves of the infected plants developed a mild veinal chlorosis interspersed with pinpoint necrotic spots which coalesced to form large necrotic areas (Fig. 1E and F). Symptoms often were more prominent toward the petiole end of leaves and on leaves of newly developed branches at the basal region of infected plants. None of the other herbaceous plants tested showed symptoms $80 \mathrm{dpi}$ and PPSMV was not detected in them by ELISA. When inoculum from PPSMV-infected pigeonpea or $N$. benthamiana plants was prepared in bentonite buffer, or in $0.1 \mathrm{M}$ phosphate, $\mathrm{pH} 8.8,0.1 \mathrm{M}$ Tris- $\mathrm{HCl}, \mathrm{pH} 8.8$ alone, or containing $0.2 \%$ monothioglycerol or $0.05 \mathrm{M}$ EDTA, or both chemicals, and inoculated to a range of plants, no infection occurred. When sap from PPSMV-infected $N$. benthamiana prepared in $2 \%$ nicotine solution was used as inoculum, $N$. benthamiana and $N$. clevelandii became infected but not the other plant species tested. PPSMV in $N$. clevelandii was erratically distributed and only a few leaves showed one to two necrotic patches 45 dpi (Fig. 1G). Mechanical transmission of PPSMV from infected $N$. benthamiana to pigeonpea or from infected pigeonpea to pigeonpea was not successful with inoculum prepared in any of the buffers used in this study, nor were plants infected by pricking leaves of young pigeonpea seedlings (10 to 15 days old) with fine needles dipped in SMD-affected pigeonpea sap extracts in $2 \%$ nicotine or in phosphate buffer, $\mathrm{pH}$ 7. Attempts to transmit PPSMV to 12 pigeonpea plants by grafting using infected $N$. benthamiana tissues also were not successful. The efficiency of virus transmission by mechanical inoculation to $N$. benthamiana plants was 10 to $40 \%$. Transmission of PPSMV from pigeonpea and $N$. benthamiana sap to $N$. benthamiana occurred only when freshly extracted sap was used immediately. PPSMV was transmitted mechanically from extracts from intact leaves of pigeonpea and $N$. benthamiana stored on ice for up to $3 \mathrm{~h}$ but not from sap extracts in 3 volumes of $2 \%$ nicotine solution stored on ice, at room temperature for $30 \mathrm{~min}$ and $60 \mathrm{~min}$, or at 4 and $-20^{\circ} \mathrm{C}$ for 24 or $48 \mathrm{~h}$.

Purification of PPSMV. The method adopted for routine purification produced the maximum virus concentration (as measured by ELISA) and the least amount of host contaminants. The partially purified preparations made from SMD-affected and from healthy pigeonpea each produced one diffuse greenish lightscattering zone of 2 to $6 \mathrm{~mm}$ in width, at similar positions in $\mathrm{CsCl}$ density gradients after centrifuging them for $3 \mathrm{~h}$ (preparative) or $18 \mathrm{~h}$ (isopycnic) (data not shown). Material from this zone from SMD-affected plants contained two major proteins of an estimated size of 32 and $52 \mathrm{kDa}$, but only a $52-\mathrm{kDa}$ protein in the similar zone from healthy pigeonpea (Fig. 2). When individual fractions from linear $\mathrm{CsCl}$ density gradients were analyzed by $12 \%$ SDSPAGE, the 32- and 52-kDa proteins were detected in fractions 3 to 5 of preparations from infected plants, but only the $52-\mathrm{kDa}$ protein in fractions from healthy preparations, and this was confirmed by WIB analysis using antiserum to PPSMV (Fig. 2). This suggested that the $52-\mathrm{kDa}$ protein was a host protein that is closely associated with PPSMV particles or particle aggregates during purification. Several attempts by varying $\mathrm{CsCl}$ gradient concentrations, centrifugation conditions, and solvent treatments were unsuccessful in eliminating or decreasing the 52-kDa host protein from purified preparations from infected pigeonpea (data not shown). By contrast, purified PPSMV preparations from $N$. ben-

TABLE 2. Detection of Pigeonpea sterility mosaic virus (PPSMV) by direct antigen coating enzyme-linked immunosorbent assay in different pigeonpea genotypes inoculated with an International Crops Research Institute for the Semi-Arid Tropics isolate of PPSMV

\begin{tabular}{llc}
\hline Pigeonpea genotype & \multicolumn{1}{c}{ Symptoms } & $A_{405 \mathrm{~nm}}$ readings $^{\mathrm{b}}$ \\
\hline ICP2376 & Chlorotic ring spots & $0.34(0.001)$ \\
ICP7035 & None & $0.27(0.002)$ \\
ICP8136 & None & $0.21(0.014)$ \\
ICP8113 & None & $0.23(0.001)$ \\
ICP15225 & None & $0.03(0.004)$ \\
ICPL85010 & None & $0.29(0.005)$ \\
ICPL87119-13 & Mild mosaic & $0.45(0.055)$ \\
ICPL87119-14 & None & $0.28(0.021)$ \\
ICPL99092 & Mild mosaic & $0.65(0.012)$ \\
BND-1 & Mild mosaic & $0.48(0.002)$ \\
Purple-1 & Severe mosaic & $0.88(0.001)$ \\
HPL24 & Mild mosaic & $0.55(0.001)$ \\
HRG-30 & Mild mosaic & $0.40(0.007)$ \\
ICPW15685 & Mild mosaic & $0.71(0.014)$ \\
ICP8863 (40 dpi) & Severe mosaic & $2.5(0.084)$ \\
ICP8863 (>75 dpi) & Mosaic on new & $1.3(0.005)$ \\
ICP8863 (>140 dpi) & growth & \\
ICP8863 (new growth & None & $0.13(0.002)$ \\
after pruning) & Severe mosaic & $1.94(0.002)$ \\
ICP8863 & Severe mosaic & $1.97(0.063)$ \\
ICP8863 (healthy control) & None & $0.14(0.001)$ \\
ICP8863 (healthy control) & None & $0.17(0.001)$ \\
ICP8863 & Mosaic & $1.68(0.009)$ \\
\hline a & &
\end{tabular}

a $\mathrm{dpi}=$ days postinoculation.

b Absorbance at $405 \mathrm{~nm}$. Values are the mean of two samples per plant tested in duplicate with standard deviations in parentheses.

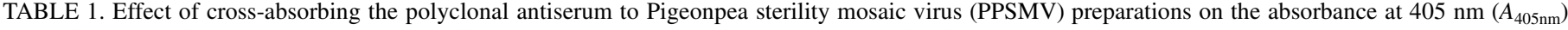
values in direct antigen coating enzyme-linked immunosorbent assay used to detect PPSMV in pigeonpea sap extracts ${ }^{\mathrm{a}}$

\begin{tabular}{|c|c|c|c|c|c|c|}
\hline \multirow[b]{2}{*}{ Antiserum dilution } & \multicolumn{3}{|c|}{ Not cross-absorbed } & \multicolumn{3}{|c|}{ Cross-absorbed $^{b}$} \\
\hline & Healthy & Infected & Ratio $^{c}$ & Healthy & Infected & Ratio $^{c}$ \\
\hline $1: 5,000$ & $1.39(0.45)$ & $1.64(0.57)$ & 1.18 & $0.08(0.02)$ & $0.39(0.10)$ & 4.87 \\
\hline $1: 10,000$ & $1.25(0.59)$ & $1.53(0.47)$ & 1.22 & $0.04(0.01)$ & $0.21(0.05)$ & 5.25 \\
\hline $1: 15,000$ & $1.34(0.54)$ & $1.58(0.34)$ & 1.18 & $0.04(0.01)$ & $0.15(0.04)$ & 3.75 \\
\hline
\end{tabular}

a Mean values for four wells from two plates with standard deviations in parenthesis.

b Antiserum absorbed with healthy pigeonpea leaf material at $10 \mathrm{mg} / \mathrm{ml}$.

c Ratio of $A_{405 \mathrm{~nm}}$ readings of PPSMV-infected and healthy pigeonpea leaves. 
thamiana contained only a negligible amount of the 52-kDa protein (Fig. 2) and WIB analysis of the fractions using antiserum to PPSMV detected only the $32-\mathrm{kDa}$ protein in fractions 3 and 4 (Fig. 2). No diffuse light-scattering band was visible in gradients loaded with preparations from healthy $N$. benthamiana plants and WIB failed to detect the 32- and 54-kDa proteins in any fractions (Fig. 2).

Properties of purified PPSMV preparations. Purified PPSMV preparations contained thin, highly flexuous filamentous virus-like particles (VLPs) of 3 to $10 \mathrm{~nm}$ in diameter (Fig. 3A and B). The particles were difficult to recognize due to their low contrast in stains and their inconsistent morphology. The VLPs occurred as branched filaments and convoluted knots resembling nucleo-

TABLE 3. Detection by direct antigen coating enzyme-linked immunosorbent assay of Pigeonpea sterility mosaic virus (PPSMV) in Nicotiana spp. and pigeonpea

\begin{tabular}{lcc}
\hline Plant material & $\begin{array}{c}\text { Leaf } \\
\text { symptoms }\end{array}$ & $\begin{array}{c}A_{405 \mathrm{~nm}} \\
\text { readings }\end{array}$ \\
\hline PPSMV-infected $N$. benthamiana & Yes & 1.42 \\
PPSMV-infected $N$. benthamiana & No & 0.27 \\
PPSMV-infected $N$. clevelandii & Yes & 1.06 \\
PPSMV-infected $N$. clevelandii & No & 0.11 \\
Raspberry bushy dwarf virus-infected & & \\
$\quad$ N. benthamiana & Yes & 0.26 \\
Tobacco mosaic virus-infected $N$. benthamiana & Yes & 0.10 \\
Healthy N. benthamiana & No & 0.11 \\
Healthy pigeonpea (ICP8863) & No & 0.17 \\
PPSMV-infected pigeonpea (ICP8863) & Yes & 1.68 \\
\hline
\end{tabular}

a Absorbance at $405 \mathrm{~nm}$. Values are the mean of two samples per plant tested in duplicate. protein particles of tenui-, tospo-, and ophioviruses. The contour lengths of these filaments varied and it was not possible to determine their lengths due to aggregation.

In cesium chloride isopycnic gradients, PPSMV preparations from infected pigeonpea and $N$. benthamiana formed a diffuse zone of density 1.22 to 1.26 and 1.23 to $1.25 \mathrm{~g} \mathrm{~cm}^{-3}$, respectively. When individual gradient fractions were assayed for PPSMV by DAC-ELISA, the maximum ELISA values occurred at a position equivalent to a density of 1.22 to $1.23 \mathrm{~g} \mathrm{~cm}^{-3}$ in preparations made from pigeonpea and $N$. benthamiana (data not shown). The fractions concentrated from this density zone had UV absorption spectra characteristic of a nucleoprotein with an $A_{260 / 280 \mathrm{~nm}}$ ratio of 1.65, an $A_{\max }$ at $256 \mathrm{~nm}$, and an $A_{\min }$ at $240 \mathrm{~nm}$. Comparable fractions from preparations of healthy pigeonpea had $A_{\max }$ at $252 \mathrm{~nm}$, $A_{\text {min }}$ at $244 \mathrm{~nm}$, and an $A_{260 / 280 \mathrm{~nm}}$ ratio of 1.44 . Purified PPSMV preparations and PPSMV concentrated by ultracentrifugation from infected pigeonpea and $N$. benthamiana plants in $2 \%$ nicotine solution or in $0.1 \mathrm{M}$ sodium phosphate buffer, $\mathrm{pH} 7.4$, containing $0.2 \% \alpha$-monothioglycerol, were not infective when inoculated mechanically to pigeonpea and $N$. benthamiana, when such plants were assessed for PPSMV by leaf symptoms and DAC-ELISA.

Serological detection of PPSMV. The purified PPSMV preparations from infected pigeonpea contained large amounts of the $52-\mathrm{kDa}$ host protein; therefore, the polyclonal antiserum produced against these preparations gave high $A_{405}$ values to healthy pigeonpea sap in DAC-ELISA (Table 1). However, cross-absorbing this antiserum with healthy pigeonpea leaf sap decreased these values without affecting significantly the detection of PPSMV (Table 1). In 10 separate experiments with SMD-affected pigeonpea cv. ICP8863 from experimental virus cultures inoculated with viruliferous $A$. cajani or by grafting, the average $A_{405}$

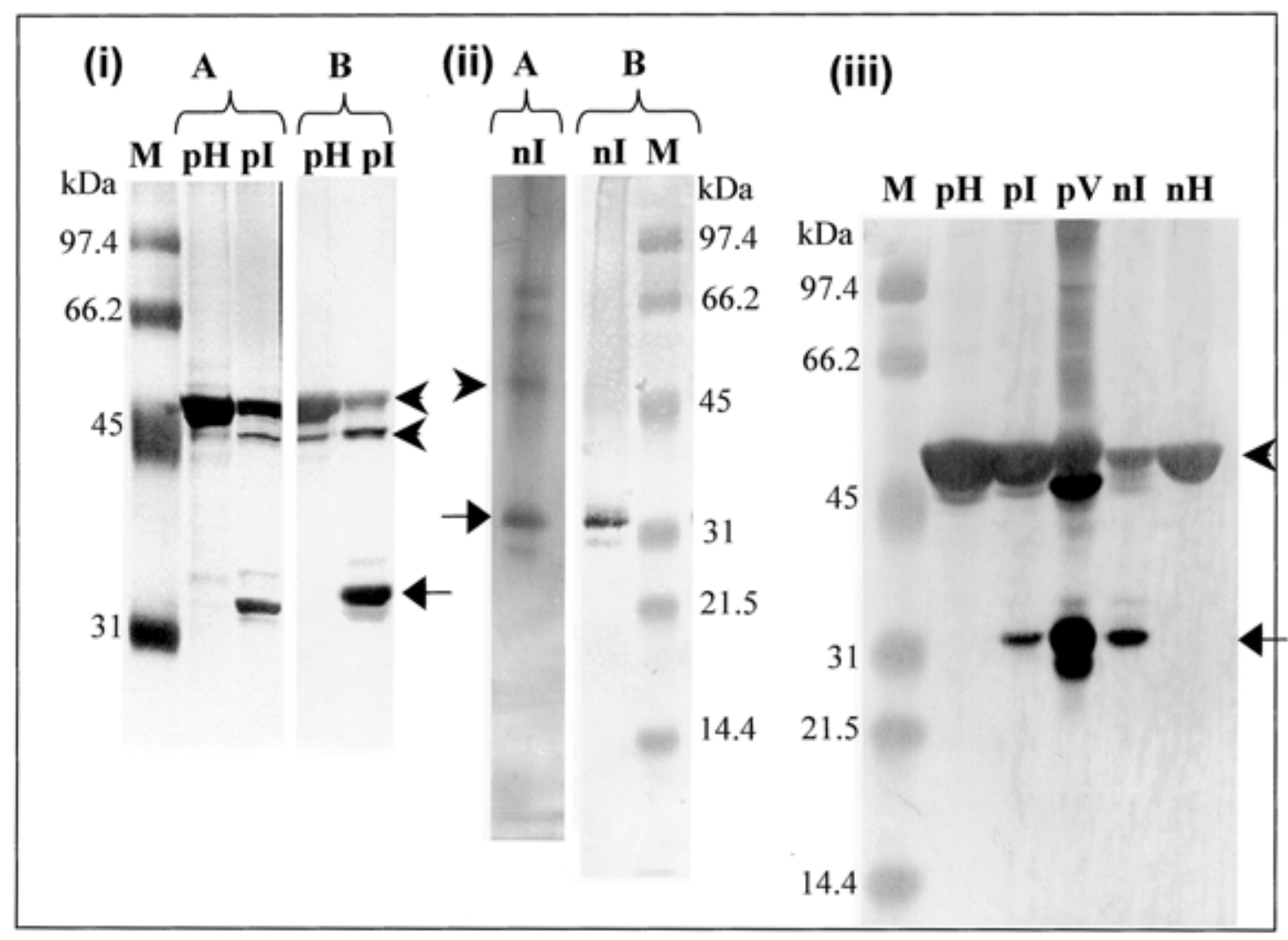

Fig. 4. Resolution of proteins from purified preparations made from pigeonpea (iA) and Nicotiana benthamiana (iiA) in 12\% denaturing polyacrylamide gels and western immunoblots of purified preparations (iB and iiB) and total leaf-sap proteins (iii). Polyacrylamide gels were stained with silver and Western blots were probed with Pigeonpea sterility mosaic virus (PPSMV) polyclonal antiserum. Lanes: pH, uninfected pigeonpea cv. ICP8863; pI, PPSMV-infected pigeonpea cv. ICP8863; nI, PPSMV-infected $N$. benthamiana; $\mathrm{nH}$, uninfected $N$. benthamiana; $\mathrm{pV}$, purified PPSMV preparations from pigeonpea; M, marker. PPSMV 32-kDa protein indicated with arrows. The 52-kDa host protein and its degraded product are indicated with arrowheads. 
ratio of infected/healthy was $>4$ (data not shown). In DACELISA, different SMD-affected pigeonpea genotypes showed markedly different PPSMV concentrations (Table 2). When 9- to 14-day-old seedlings of pigeonpea cv. ICP8863 were inoculated with mites, PPSMV was detected in these plants 10 to $12 \mathrm{dpi}$ (Table 2) and they usually showed symptoms 14 to $18 \mathrm{dpi}$. As these plants continued to grow, prominent symptoms became restricted to young new growth and such leaves gave high ELISA values when compared with the older leaves. After $\approx 140$ dpi, plants were largely symptomless and were negative for PPSMV in ELISA (Table 2). However, when these plants were pruned, the newly produced leaves showed clear SMD symptoms and sap extracts from them reacted strongly in ELISA for PPSMV (Table 2). DAC-ELISA for PPSMV also detected the virus in symptomatic leaves of infected $N$. benthamiana and $N$. clevelandii (Table 3). Attempts to detect PPSMV by DAC-ELISA in extracts of groups of more than $50 \mathrm{~A}$. cajani from SMD-affected pigeonpea were not successful. In DAC-ELISA, no reaction was detected with leaf sap from $N$. benthamiana plants infected with Raspberry bushy dwarf virus (RBDV) and Tobacco mosaic virus (TMV) (Table 3). In reciprocal ELISA, PPSMV antiserum did not react with MSpV, RWMV, MiLV, and CPsV antigens and antisera to each of these four viruses, and antiserum to HPV and to PBNV did not react with PPSMV antigen (data not shown).

Identification of protein and nucleic acid associated with PPSMV preparations. Electrophoresis of proteins from purified preparations (Fig. 4i and ii) and total leaf proteins from healthy and PPSMV-infected pigeonpea and $N$. benthamiana (Fig. 4iii) detected major proteins of estimated sizes of 32 and $52 \mathrm{kDa}$. The $32-\mathrm{kDa}$ protein was detected only in PPSMV-infected preparations, whereas the $52-\mathrm{kDa}$ protein was common in preparations of PPSMV-infected as well as in healthy plants (Fig. 4). Each of these proteins was detected in WIB by the PPSMV antiserum (Fig. 4iB, iiB, and iii). The PPSMV-specific 32-kDa protein was detected in all PPSMV-infected pigeonpea plants whether they were infected via viruliferous $A$. cajani or by grafting with in- fected scions. It also was detected in all of 38 samples of SMDaffected pigeonpea plants collected from more than 12 different field locations in Andhra Pradesh and Karnataka states in India. However, it was not detected in healthy pigeonpea and $N$. benthamiana or in $N$. benthamiana infected with TMV or RBDV. To determine the identities of the $32-$ and $52-\mathrm{kDa}$ proteins, tryptic fragments of these proteins from MALDI-ToF analysis were used for database searching. The $32-\mathrm{kDa}$ protein found no significant matches, whereas the $52-\mathrm{kDa}$ protein present in infected and healthy preparations detected matches $(P<0.05)$ with the large chain of ribulose-1, 5-bisphosphate carboxylase (rbcl) of pigeonpea (Accession No. AB045791) and of several members of the family Papilionoideae (data not shown).

Enzymatic digestions of the nucleic acid extracts from purified PPSMV preparations with DNase and RNase indicated that it consisted of RNA (data not shown). The viral RNA migrated as five to seven discrete species in nondenaturing and denaturing agarose gels (Fig. 5). They were tentatively called (in order of decreasing size, given in parenthesis, estimated by comparing their mobility with ssRNA markers in denaturing gels), R1 $(\approx 6.8 \mathrm{~kb}), \mathrm{R} 2$ $(\approx 2.7 \mathrm{~kb})$, R3 $(\approx 2.1 \mathrm{~kb})$, R4 $(\approx 1.6 \mathrm{~kb})$, R5 $(\approx 1.4 \mathrm{~kb})$, R6 $(\approx 1.2 \mathrm{~kb})$, and $\mathrm{R} 7(\approx 1.1 \mathrm{~kb})$. Segment R1 was present in only some preparations and most preparations also contained some very minor bands of $<1 \mathrm{~kb}$ (Fig. $5 \mathrm{~A}$ and $\mathrm{B}$ ). The molar proportion of these RNA segments varied from preparation to preparation. Segments R4 and R5, and R6 and R7, migrated very closely, but discretely even in denaturing gels. All these nucleic acid species were sensitive to digestion with RNase A in high and low salt conditions, indicating that they were ssRNA (data not shown). None of these nucleic acid species were detected in purified preparations from healthy pigeonpea.

Fractionation of the viral RNA with $2 \mathrm{M} \mathrm{LiCl}$ precipitation recovered the viral RNA segments from both the supernatant and pellet fractions (Fig. 5B). These segments from each fraction comigrated in nondenaturing (Fig. 5B, lanes 1 and 2) and denaturing (Fig. 5B, lanes 5 and 6) gels, and their profiles were
A

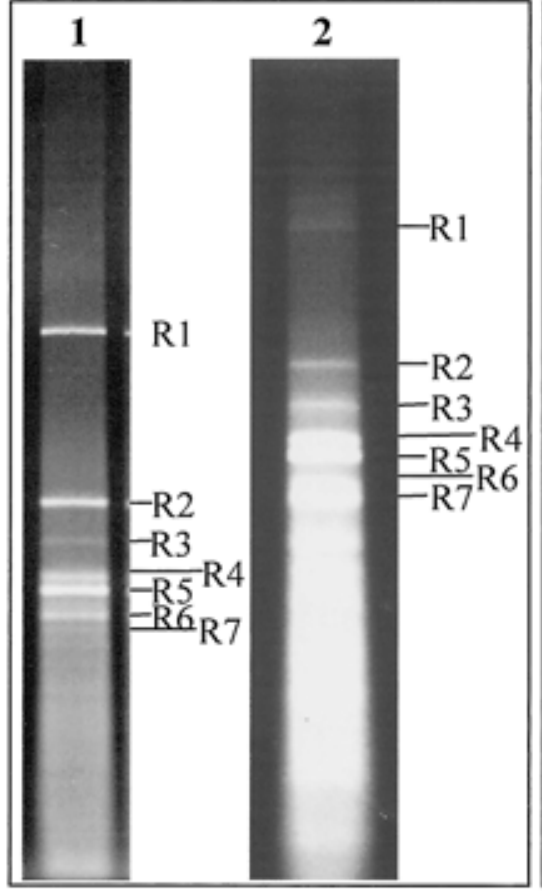

B

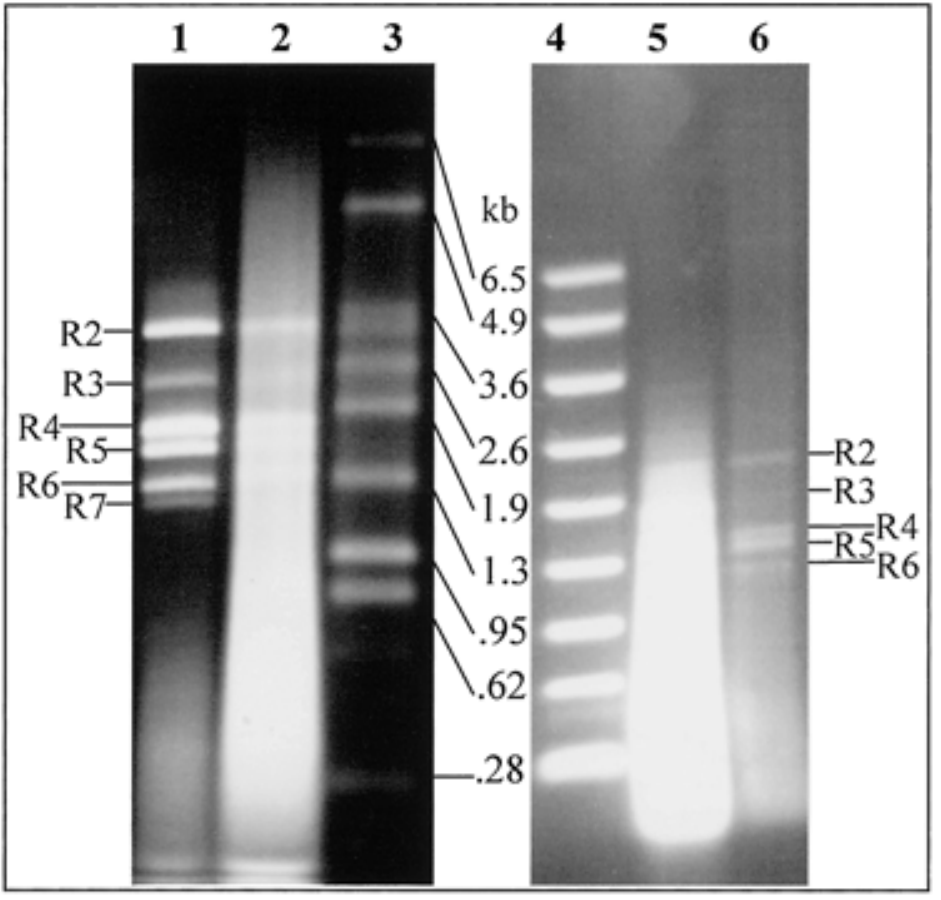

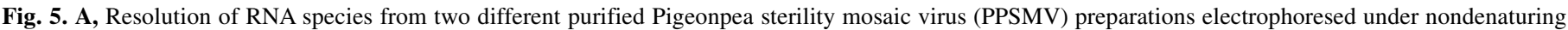

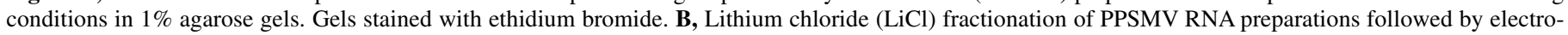

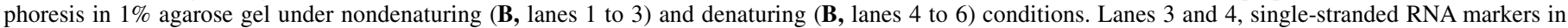
nondenaturing and denaturing gels. Gels were stained with ethidium bromide. Lanes 1 and 6, LiCl-soluble fraction; lanes 2 and 5, pellet fraction. 
similar to those in unfractionated samples. However, most of the smaller RNA species $(<1 \mathrm{~kb})$ were retained in the pellet fraction (Fig. 5B, lanes 2 and 5). The RNA in the $\mathrm{LiCl}$ supernatant and pellet fractions was sensitive to RNase A treatment in low and high salt conditions, indicating that they are ssRNA (data not shown). We have no explanation for the apparent retention of PPSMV RNA in the $\mathrm{LiCl}$ supernatant. However, it could be due to the high secondary structure of PPSMV RNA. RNA isolated from purified PPSMV preparations was not infective when inoculated mechanically to pigeonpea and $N$. benthamiana.

Molecular cloning of PPSMV nucleic acid, Northern hybridization, and RT-PCR. Sequence obtained from nine cDNA clones had no matches in the databases (data not shown). One cDNA clone ( $c$ d1.1; sequence Accession No. AJ439561) with an insert size of $764 \mathrm{bp}$, when labeled with DIG-dUTP, hybridized with segment R5 $(\approx 1.4 \mathrm{~kb})$ present in purified PPSMV preparations separated in nondenaturing (Fig. 6, lane 5) and denaturing (Fig. 6, lane 2) conditions. The probe also hybridized with R5 present in the RNA in the $\mathrm{LiCl}$ supernatant and pellet fractions separated under denaturing conditions (Fig. 6, lanes 3 and 4) and also with total nucleic acids extracted from PPSMV-infected pigeonpea and $N$. benthamiana plants (data not shown), but not in preparations made from healthy plants (Fig. 6, lane 1). Other cDNA clones have yet to be tested by northern hybridization.

The two primers (SM-1 and SM-2), designed from the $c d 1.1$ nucleotide sequence, amplified specifically a 321-bp product from RNA from purified PPSMV preparations and from total RNA extracts from leaves of PPSMV-infected pigeonpea and $N$. benthamiana plants (Fig. 7). The primers also amplified the 321-bp product from 47 SMD-affected pigeonpea plants from various locations in peninsular India but not from RNA from any healthy pigeonpea plants, or from five purified preparations from healthy pigeonpea plants grown in growth chambers, or from

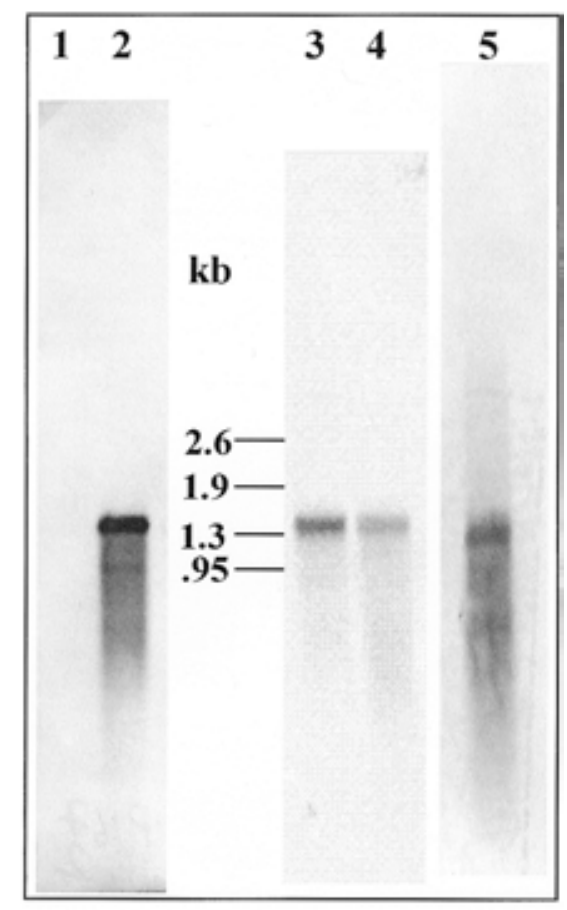

Fig. 6. Northern blot hybridization using digoxygenin (DIG-labeled $c d 1.1$ insert as probe). Lane 1, total RNA from healthy pigeonpea; lanes 2 and 5, purified Pigeonpea sterility mosaic virus (PPSMV) RNA; lane 3, LiClsoluble fraction of PPSMV RNA; and lane 4, LiCl pellet fraction. RNA preparations in lanes 1 to 4 were separated in formaldehyde denaturing $1 \%$ agarose gel, and in lane 5 in a nondenaturing $1 \%$ agarose gel. The DIGlabeled probe hybridized specifically with PPSMV RNA-5 in all the treatments. The position of the Promega ssRNA marker segments are indicated along lane 3 . leaves of healthy $N$. benthamiana plants or such plants infected with RBDV or TMV (data not shown). The 321-bp product also was amplified from RNA extracted from SMD-affected pigeonpea plants inoculated experimentally with viruliferous $A$. cajani and also from graft-inoculated plants. Attempts to detect PPSMV by RT-PCR in A. cajani were unsuccessful, due presumably to the difficulties in isolating total RNA from these organisms.

\section{DISCUSSION}

Using the developed purification protocol, we consistently isolated VLPs associated with PPSMV from SMD-affected pigeonpea plants. This virus was transmitted experimentally to pigeonpea plants by $A$. cajani, and these plants produced typical SMD symptoms, and PPSMV was detected in them serologically and by RT-PCR (Tables 2 and 3; Fig. 7). Additionally, PPSMV was detected by ELISA in all SMD-affected pigeonpea plants infected either experimentally by $A$. cajani or by grafting, or naturally in the field at several different locations in India, and in infected accessions of wild pigeonpea, Cajanus scaraboeoides. Furthermore, it was detected in various pigeonpea genotypes showing the different symptom forms of the disease (Table 2). Taken together, these combined data show the complete and specific association of PPSMV with SMD and provide very strong circumstantial evidence that PPSMV is the causal agent of SMD. Unequivocal evidence that PPSMV is the causal agent depends on fulfilling Koch's postulates but several technical difficulties prevent this, including the unstable nature of the virus and the difficulty of infecting pigeonpea by mechanical inoculation.

The difficulties we experienced in purifying PPSMV from pigeonpea probably is due to the large amounts of host interfering components and to the unusual nature and lability of the VLPs and their apparent close association with the 52-kDa host component. Consequently, purified PPSMV preparations from pigeonpea contained large amounts of contaminating host proteins that proved difficult to eliminate (Figs. 2 and 4) and their occurrence affected significantly the subsequent analysis of viral protein and nucleic acid. Such materials (possibly polysaccharides and/or polyphenols) interfered with the clear visibility of the RNA bands, especially in denaturing agarose gels (Fig. 5, lanes 2 and 5), and greatly affected the subsequent enzymatic reactions used in our attempts to clone and sequence the different RNA species. The use of various protein denaturing agents such as guanidium thiocynate and TriZoal reagent (Gibco-BRL, UK), and treatments with proteinase $\mathrm{K}$ to try to eliminate this interfering material were not successful.

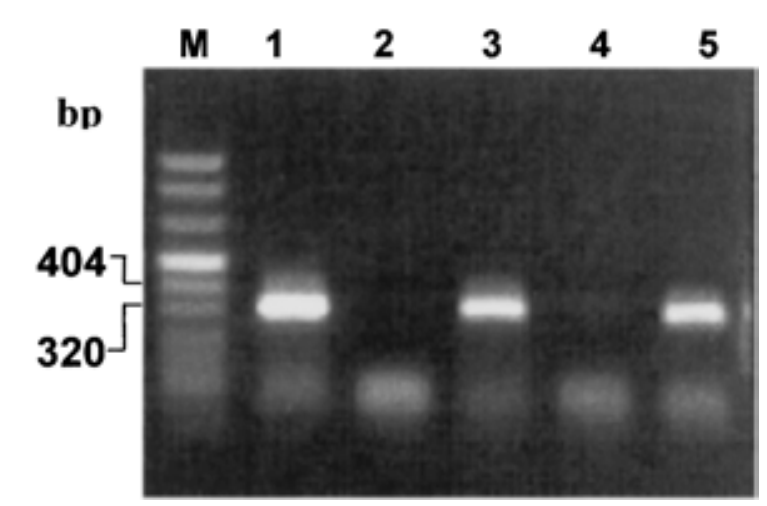

Fig. 7. Resolution of reverse transcription-polymerase chain reaction (RTPCR) products in 1\% agarose gel. Lanes contain the PCR products from templates of total RNA extracts from Pigeonpea sterility mosaic virus (PPSMV)infected pigeonpea (lane 1) and $N$. benthamiana (lane 3); total RNA from healthy pigeonpea (lane 2) and $N$. benthamiana (lane 4); and nucleic acid from PPSMV preparations purified from infected pigeonpea (lane 5); lane M, molecular weight marker. 
Purified PPSMV preparations from infected N. benthamiana contained much less contaminating host proteins than those from pigeonpea (Fig. 4ii). However, the poor frequency of mechanical transmission of PPSMV to this host, and its erratic distribution and long incubation period in such plants, restricted the routine generation of adequate numbers of infected plants for purification. Nevertheless, the infection of $N$. benthamiana and $N$. clevelandii by PPSMV is the first report both of the mechanical transmission of PPSMV and of it infecting a species outside the genus Cajanus. Our study suggests that previous failures to transmit PPSMV by mechanical inoculation (43) may be due to its poor transmissibility to, and its very slow development of symptoms in, these herbaceous host species. Without the serological assay for detecting PPSMV, such infected plants probably would have gone unnoticed. The feeding of eriophyid mites is known to be restricted largely to the epidermal cells of plants; therefore, it might be expected that all eriophyid mite-transmitted agents should be transmitted by mechanical inoculation. Indeed, all the well-characterized viruses transmitted by eriophyid mites are transmitted by mechanical inoculation, although for some, like PPSMV, with only poor efficiency $(21,38)$. Despite the mechanical transmission to herbaceous plants of PPSMV in sap extracts, attempts to transmit PPSMV using purified VLPs and nucleic acid preparations were unsuccessful. Possibly, the harsh treatments used in the purification protocol might have destroyed virus infectivity. Certainly, the infectivity of PPSMV in plant sap extracts is very short lived and, although the high polyphenolic compounds present in pigeonpea may account for this in this species, PPSMV infectivity also was short lived in sap of infected $N$. benthamiana, suggesting that the poor infectivity is probably due to the labile nature of the virus.

Purified PPSMV preparations contained very thin, highly flexuous filamentous VLPs of undetermined length and 3 to $10 \mathrm{~nm}$ in width that, in the electron microscope, appeared branched and coiled (Fig. 3). Their detection by electron microscopy was very difficult due to their apparent low concentration in preparations, their poor contrast in stains, and the presence of large amounts of contaminating host proteins. Attempts to trap these VLPs on electron microscope grids with cross-absorbed antiserum to PPSMV did not assist detection of these particles. The properties of PPSMV indicate that it is a previously undescribed virus with an unusual combination of properties. In the size and appearance of its VLPs and the number and sizes of its protein and RNA components, it is similar to viruses in the genus Tenuivirus (12). However, all tenuiviruses are phloem limited, transmitted by Delphacid plant-hoppers, and infect plant species in the family Poeaceae (12). Our recent ultrastructural studies of PPSMVinfected pigeonpea and $N$. benthamiana plants identified 100- to $150-\mathrm{nm}$ quasispherical membrane-bound bodies (MBBs) and fibrous inclusions (FIs) (30). The MBBs were labeled in situ specifically with the cross-absorbed PPSMV antiserum, indicating that they contain the PPSMV-specific 32-kDa antigen. The FIs found in PPSMV-infected cells are possibly a nonstructural inclusion protein of PPSMV (30). Although tenuiviruses do not produce cellular inclusion bodies that resemble the MBBs found in PPSMV-infected cells, their nonstructural protein inclusions (NCP) in infected cells resemble the FIs of PPSMV $(10,11,30)$. PPSMV also resembles tospoviruses, which share many properties with tenuiviruses (12). Thus, the filamentous VLPs of PPSMV resemble the nucleoprotein particles of TSWV (50) and the MBBs of PPSMV are similar to, though larger than, those of TSWV (23). Despite these similarities, serological tests failed to detect any relationship of PPSMV to MSpV, a tenuivirus endemic in the Indian subcontinent, or to PBNV, a tospovirus endemic in India. Furthermore, whereas tospoviruses, tenuiviruses, and several other membrane-associated plant viruses are transmitted in a persistent and often propagative manner by their invertebrate vector species (52), PPSMV is transmitted by eriophyid mites and our recent studies indicate that $A$. cajani transmits it in a semipersistent manner (24). Moreover, the partial nucleotide sequence of one of the PPSMV RNA species and the monoisotopic masses of the $32-\mathrm{kDa}$ nucleoprotein show no similarity with these, or with any other, viruses in the databases. The VLPs of PPSMV show some morphological similarity to species in the genus Ophiovirus, but members of this genus differ from PPSMV in the number and sizes of their protein and RNA components (52), and there was no serological relationship detected between PPSMV and three members (CPsV, MiLV, and RWMV) of this genus.

PPSMV shows most similarity with HPV (19). Each of these viruses is transmitted by eriophyid mites, has 4 to 7 RNA species, a virus-specific $32-\mathrm{kDa}$ protein, MBBs of similar size and morphology, and is mechanically transmitted in sap extracts but not in purified preparations $(2,13,19,30,34)$. However, no serological relationship was detected between these two viruses. In purified preparations of PPSMV and HPV, no structures comparable to the MBBs were detected (19). For each virus their MBBs were heavily labeled with their respective antiserum to purified VLPs; therefore, it is possible that these particles are released from ruptured MBBs during the purification process. However, attempts to detect MBBs in purified PPSMV preparations concentrated without the use of detergents and organic solvents, or by fixing sap extracts in glutaraldehyde, were not successful (data not shown). It is likely that the lack of infectivity of purified preparations could be due to the length of time that the VLPs are in vitro, or that intact MBBs are required for infectivity, and that these are destroyed in the purification process. MBBs similar to those detected in PPSMV- and HPV-infected plants also were detected in plants affected with other eriophyid mite-transmitted agents that cause fig mosaic, wheat spot mosaic, thistle mosaic, and rose rosette diseases $(1,6,14)$. The causal agents of these diseases remain unknown but, in view of the similarities of some of their properties to PPSMV and HPV, the purification protocol described here for PPSMV might prove useful in the characterization of these agents. Based on our data presented here, it now seems more likely that PPSMV, HPV, and probably these other eriophyid miteborne agents with MBB-associated structures represent species in a new genus of plant viruses, as suggested earlier on the basis of ultrastructural studies $(1,30)$.

Finally, the isolation and characterization of PPSMV as the probable causal agent of SMD has enabled the development of serological and nucleic acid-based tools necessary for its unequivocal detection in plants. These tools are contributing significantly to ongoing research aimed at understanding the epidemiology of this very serious disease in the Indian subcontinent and at developing pigeonpea genotypes with resistance to it.

\section{ACKNOWLEDGMENTS}

This document is an output from a project (R7452) funded by the United Kingdom Department for International Development (DFID) under the Crop Protection Program for the benefit of developing countries. The views expressed are not necessarily those of DFID. Work at SCRI is grant-aided by the Scottish Executive Environment and Rural Affairs Department (SEERAD). Studies on nonindigenous organisms at SCRI were done under the conditions of a license from SEERAD. We thank S. V. Reddy and N. Kulkarni (ICRISAT) for maintaining SMD inoculum; G. Duncan and C. McQuade (SCRI) and N. Harris (Mordun Research Institute, Edinburgh) for technical help; S. Jensen and R. Milne for generous gifts of virus antiserum or antigen; L. Lane for providing information on HPV; and J. M. Lennè (ICRISAT) for encouragement.

\section{LITERATURE CITED}

1. Ahn, K.-K., Kim, K. S., Gergerich, R. C., Jensen, S. G., and Anderson, E. J. 1996. Comparative ultrastructure of double membrane-bound particles and inclusions associated with eriophyid mite-borne plant diseases of unknown etiology: A potentially new group of plant viruses. J. Submicrosc. Cytol. Pathol. 28:345-355. 
2. Ahn, K.-K., Kim, K. S., Gergerich, R. C., and Jensen, S. G. 1998. High plains virus of corn and wheat: Ultrastructural and serological aspects. J. Submicrosc. Cytol. Pathol. 30:563-571.

3. Alioto, D., Gangemi, M., Deaglio, S., Sposato, P., Noris, E., Luisoni, E., and Milne, R. G. 1999. Improved detection of citrus psorosis virus using polyclonal and monoclonal antibodies. Plant Pathol. 48:735-741.

4. Altschul, S. F., Gish, W., Miller, W., Myers, E. W., and Lipman, D. J. 1990. Basic local alignment search tool. J. Mol. Biol. 215:403-410.

5. Blake, M. S., Johnston, K. H., Russell-Jones, G. J., and Gotschlich, E. C. 1984. A rapid, sensitive method for detection of alkaline phosphatase-conjugated anti-antibody on Western blots. Ann. Biochem. 136:175179.

6. Bradfute, O. E., Whitmoyer, R. E., and Nault, L. R. 1970. Ultrastructure of plant leaf tissue infected with mite-borne viral-like pathogens. Proc. Electron Microsc. Soc. Am. 28:178-179.

7. Capoor, S. P. 1952. Observations on pigeonpea sterility disease in Bombay. Indian J. Agric. Sci. 22:271-274.

8. Clausear, K. R., Hall, S. C., Smith, D. M., Webb, J. W., Andrews, L. E., Tran, H. M., Sabastein, L. B., and Burlingame, A. L. 1995. Rapid mass spectrometric peptide sequencing and mass matching for characterization of human melanoma proteins isolated by two-dimensional PAGE. Proc. Natl. Acad. Sci. USA 92:5072-5076.

9. de Avila, A. C., Huguenot, C., Rescende, R. D. O., Kitajima, E. W., Goldback, R. W., and Peters, D. 1990. Serological differentiation of 20 isolates of tomato spotted wilt virus. J. Gen. Virol. 71:2801-2807.

10. Espinoza, A. M., Hernandez, M., Pereira, R., Falk, B., and Medina, V. 1992. In situ immunogold labeling analysis of the Rice hoja blanca virus nucleoprotein and major noncapsid protein. Virology 191:619-627.

11. Espinoza, A. M., Pereira, R., Macaya-Lizano, A. V., Hernandez, M., Goulden, M., and Rivera, C. 1991. Comparative light and electron microscopic analyses of tenuivirus major noncapsid protein (NCP) inclusion bodies in infected plants and of the NPC in vitro. Virology 195:156-166

12. Falk, B. W., and Tsai, J. H. 1998. Biology and molecular biology of Tenuivirus. Annu. Rev. Phytopathol. 36:139-163.

13. Forster, R. L., Seifers, D. L., Strausbaugh, C. A., Jensen, S. G., Ball, E. M., and Harvey, T. L. 2001. Seed transmission of the High Plains virus in sweet corn. Plant Dis. 85:696-699.

14. Gergerich, R. C., Kim, K. S., and Kitajima, E. W. 1989. A particle of unique morphology associated with a disease in rose in Northwest Arkansas. Phytopathology 73:500-501.

15. Ghanekar, A. M., Sheila, V. K., Beniwal, S. P. S., Reddy, M. V., and Nene, Y. L. 1992. Sterility mosaic of pigeonpea. Pages 415-428 in: Plant Diseases of International Importance, Vol. 1. Diseases of Cereals and Pulses. U. S. Singh, A. N. Mukhopadhyay, J. Kumar, and H. S. Chaube, eds. Prentice Hall, New Jersey.

16. Gispert, C., Perring, T. M., and Creamer, R. 1998. Purification and characterization of peach mosaic virus. Plant Dis. 82:905-908.

17. Hobbs, H. A., Reddy, D. V. R., Rajeshwari, R., and Reddy, A. S. 1987. Use of direct antigen coating and protein A coating ELISA procedures for detection of three peanut viruses. Plant Dis. 71:747-749.

18. James, D., and Howell, W. E. 1998. Isolation and partial characterization of a filamentous virus associated with peach mosaic disease. Plant Dis. 82:909-913.

19. Jensen, S. G., Lane, L. C., and Seifers, D. L. 1996. A new disease of maize and wheat in the high plains. Plant Dis. 80:1387-1390.

20. Jones, A. T. 1993. Experimental transmission of viruses in diagnosis. Pages 49-72 in: Diagnosis of Plant Virus Diseases. R. E. F. Matthews, ed. CRC Press, Boca Raton, FL.

21. Jones, A. T. 2000. Black currant reversion disease-The probable causal agent, eriophyid mite vectors, epidemiology and prospects for control. Virus Res. 71:71-84

22. Kannaiyan, J., Nene, Y. L., Reddy, M. V., Ryan, J. G., and Raju, T. N. 1984. Prevalence of pigeonpea diseases and associated crop losses in Asia, Africa and the Americas. Trop. Pest Manage. 30:62-71.

23. Kitajima, E. W., Avila, A. C. D., Resebde, R. D. O., Goldbach, R. W., and Peters, D. 1992. Comparative cytopathology and immunogold labeling studies on different isolates of Tomato spotted wilt virus. J. Submicroc. Cytol. Pathol. 24:1-14.

24. Kulkarni, N. K., Kumar, P. L., Muniyappa, V., Jones, A. T., and Reddy, D. V. R. 2002. Transmission of Pigeonpea sterility mosaic virus by the eriophyid mite, Aceria cajani (Acari: Arthropoda). Plant Dis. 86:12971302.

25. Kumar, P. L., Fenton, B., and Jones, A. T. 1999. Identification of Cecidophyopsis mites (Acari: Eriophyidae) based on variable simple sequence repeats of ribosomal DNA internal transcribed spacer-1 sequence via multiplex PCR. Insect Mol. Biol. 8:347-358.

26. Kumar, P. L., Jones, A. T., Sreenivasulu, P., and Reddy, D. V. R. 2000. Breakthrough in the identification of the causal virus of pigeonpea sterility mosaic disease. J. Mycol. Plant Pathol. 30:249.

27. Kumar, P. L., Jones, A. T., Sreenivasulu, P., Fenton, B., and Reddy, D. V. R. 2001. Characterization of a virus from pigeonpea with affinities to species in the genus Aureusvirus, family Tombusviridae. Plant Dis. $85: 208-215$.

28. Kumar, P. L., Fenton, B., Duncan, G. H., Jones, A. T., Sreenivasulu, P., and Reddy, D. V. R. 2001. Assessment of variation in Aceria cajani (Acari: Eriophyidae) using analysis of nuclear rDNA ITS regions and scanning electron microscopy: Implications for the variability observed in host plant resistance to pigeonpea sterility mosaic disease. Ann. Appl. Biol. 139:61-73.

29. Kumar, P. L., Jones, A. T., Duncan, G. H., Roberts, I. M., and Reddy, D. V. R. 2001. Characterization of a novel mite-transmitted virus associated with pigeonpea sterility mosaic disease. (Abstr.) Phytopathology 91(suppl.):S51.

30. Kumar, P. L., Duncan, G. H., Roberts, I. M., Jones, A. T., and Reddy, D. V. R. 2002. Cytopathology of Pigeonpea sterility mosaic virus in pigeonpea and Nicotiana benthamiana: Similarities with those of eriophyid mite-borne agents of undefined etiology. Ann. Appl. Biol. 140:87-96.

31. Laemmli, U. K. 1970. Cleavage of structural proteins during the assembly of the head of bacteriophage T4. Nature 277:680-685.

32. Lane, L. C. 1986. Propagation and purification of RNA plant viruses. Pages 687-996 in: Methods in Enzymology, Vol. 118. A. Weissbach and H. Weissbach, eds. Academic Press, Orlando, FL.

33. Lemmetty, S., Latvala, S., Jones, A. T., Susi, P., McGavin, W. J., and Lehto, K. 1997. Purification and properties of a new virus from blackcurrant, its affinities with nepoviruses, and its close association with black currant reversion disease. Phytopathology 87:404-413.

34. Mirabile, J., Scholthof, K.-B. G., and Scholthof, H. B. 2001. Biological studies and molecular characterization of the High Plains Disease pathogen. (Abstr.) Phytopathology 91(suppl.):S63.

35. Mitra, M. 1931. Report of the Imperial Mycologist. Sci. Rep. Agric. Res. Inst. Pusa 19:58-71.

36. Nene, Y. L. 1995. Sterility mosaic of pigeonpea: The challenge continues. Indian J. Mycol. Plant Pathol. 25:1-11.

37. Nene, Y. L., and Reddy, M. V. 1976. Screening for resistance to sterility mosaic of pigeonpea. Plant Dis. Rep. 60:1034-1036.

38. Oldfield, G., and Proeseler, G. 1996. Eriophiod mites as vectors of plant pathogens. Pages 259-275 in: Eriophyoid Mites-Their Biology, Natural Enemies and Control. E. E. Lindquist, M. W. Sabelis, and J. Bruin, eds. Elsevier Science B.V., The Netherlands.

39. Parker, K. C., Garrels, J. I., Hines, W., Butler, E. M., Mckee, A. H. Z., Patterson, D., and Martin, S. 1998. Identification of yeast proteins from two-dimensional gels: Working out spot cross-contamination. Electrophoresis 19:1920-1932.

40. Peterschmitt, M., Ratna, A. S., Sacks, W. R., Reddy, D. V. R., and Mughogho, L. K. 1991. Occurrence of an isolate of maize stripe virus on sorghum in India. Ann. Appl. Biol. 118:57-70.

41. Reddy, A. S., Kulkarni, N. K., Kumar, P. L., Jones, A. T., Muniyappa, V., and Reddy, D. V. R. 2002. A new graft inoculation method for screening resistance to Pigeonpea sterility mosaic virus. Int. Chickpea Pigeonpea Newsl. 9:44-46.

42. Reddy, M. V., Raju, T. N., and Lenne, J. M. 1998. Diseases of pigeonpea. Pages 540-558 in: The Pathology of Food and Pasture Legumes. D. J. Allen and J. M. Lenne, eds. CAB International, Wallingford, U.K.

43. Reddy, M. V., Reddy, D. V. R., and Sacks, W. R. 1994. Epidemiology and management of sterility mosaic disease of pigeonpea. Pages 29-32 in: Proc. Int. Symp. Rose Rosette and Other Eriophyid Mite-Transmitted Plant Disease Agents of Uncertain Etiology. Iowa State University, Ames.

44. Reddy, M. V., Sheila, V. K., Murthy, A. K., and Padma, P. 1995. Mechanism of resistance to Aceria cajani in pigeonpea. Int. J. Trop. Plant Dis. 13:51-57.

45. Roggero, P., Ciuffo, M., Vaira, A. M., Accotto, G. P., Masenga, V., and Milne, R. G. 2000. An Ophiovirus isolated from lettuce with big-vein symptoms. Arch. Virol. 145:2629-2642.

46. Sambrook, J., and Russell, D. W. 2000. Molecular Cloning: A Laboratory Manual. 3rd ed. Cold Spring Harbor Laboratory, Cold Spring Harbor, NY.

47. Sammons, D. W., Adams, L. D., and Nishizawa, E. E. 1981. Ultrasensitive color staining of polypeptides in polyacrylamide gels. Electrophoresis 2:135-141.

48. Seth, M. L. 1962. Transmission of pigeonpea sterility by an eriophyid mite. Indian Phytopathol. 15:225-227.

49. Singh, A. K., Rathi, Y. P. S., and Agarwal, K. C. 1999. Sterility mosaic of pigeonpea: A challenge of 20th century. Indian J. Virol. 15:85-92.

50. Tsuda, S., Hanada, K., Hidaka, S., Minobe, Y., Kameya-Iwaki, M., and 
Tomaru, K. 1992. The presence of three pairs of possibly complementary RNA species in isolated nucleocapsid material of Tomato spotted wilt virus. Ann. Phytopathol. Soc. Jpn. 58:393-404.

51. Vaira, A. M., Milne, R. G., Accotto, G. P., Luisoni, E., Masenga, V., and Lisa, V. 1997. Partial characterization of a new virus from ranunculus with a divided RNA genome and circular supercoiled thread-like particles. Arch. Virol. 142:2131-2146.

52. Van Regenmortel, M. H. V., Fauquet, C. M., Bishop, D. H. L., Carstens, E., Estes, M., Lemon, S., Maniloff, J., Mayo, M. A., McGeoch, D., Pringle, C. R., and Wickner, R. B. 2000. Virus Taxonomy. Seventh Report of the International Committee on Taxonomy of Viruses. Academic Press, New York. 